\section{Kulturarv - et relativt begreb}

\author{
AfFrank Birkebak Museumsinspektør, \\ Roskilde
}

- Artiklen bygger på et foredrag, holdt på Det Kongelige Bibliotek februar 2001. Foredraget indgik i en række om begrebet kulturværdi.

\section{Umistelig tilfældighed}

$\mathrm{I}$ 1160 tog biskop Absalon en beslutning, som vi i dag ikke tøver med at betegne som af global interesse.

Han besluttede at bygge en kirke - Roskilde Domkirke - som i sit arkitektoniske udtryk er så enestående, at den i dag er optaget på UNESCO's liste over verdens umistelige kulturarv. Ikke nok med at den i sin tidlige teglstensgotik er et arkitektonisk mesterværk. Som kongelig begravelseskirke er den af betydning for vores nationale selvforståelse, og i den forstand umistelig. Så der er, set med nutidens briller, god grund til, at kirken har opnået status, som værdig til listen over menneskehedens fineste monumenter. Men samtidig er det også udtryk for, at historien har en ironisk dimension.

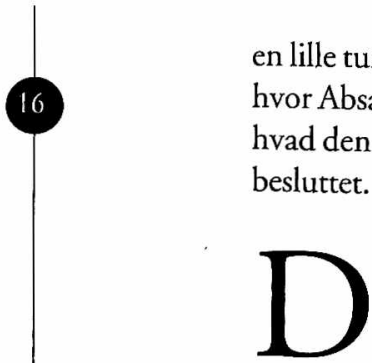

For at forstå det, må man tage på Blåtand byggede sin trækirke, da han grundlagde rigets første hovedstad. Men den kirke var for længst væk, da Absalon tog sit initiativ. I stedet lå der en måske kun 60 år gammel romansk basilika, bygget i den fine hvide frådsten, som er Roskildes lokale stenbyggemateriale. Så vidt de sparsomme arkæologiske undersøgelser lader ane, har det været et pragtfuldt romansk stenhus - måske landets bedste - og under alle omstændigheder af en kvalitet, som ville have beriget vores arkitekturarv i betragtelig grad.

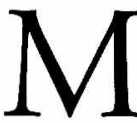
en da Absalon bestemte sig for sit store byggeprojekt, var overvejelser om den romanske basilikas værdi og betydning som arv uden betydning for hans beslutning. Hans - og tidens - dynamik var ikke til en passiv tilbageskuen. Den slags bevaringsovervejelser var fremmede for tiden - og i mange århundreder derefter. Vores historie er fyldt med eksempler på brutal ødelæggelse af det, vi kalder kulturarv. F.eks. var en af reformationens følgevirkninger i midten af 1500-tallet nedbrydning af kirker og klostre som genbruges til byggematerialer $i$ andre huse, og en billedstorm mod gotikkens kirkekunst, en kirkekunst, som kunne have givet et enestående bidrag til vores billedkunstarv. Men langt vigtigere i samtiden end bevaring af tidligere generationers ypperligste frembringelser, var det tværtimod at få dem fjernet, fordi de blev betragtet som et udtryk for vranglære og magtmisbrug, og ikke som generationers arv til eftertiden. Hvis vi bliver et øjeblik mere ved domkirken i Roskilde, men går et par hundrede år frem i tiden, så ligger der som bekendt i dag lige øst for kirken et af landets fine barokanlæg, Det Kongelige Palæ, opført af arkitekten Lauritz de Thura i 1730 'erne. Men inden der var plads til det byggeri, måtte man - med skyldig reference til skæbnen, den skælm - nedrive en imponerende bispegård bygget af Absalon. Da den lå færdigbygget i 1100-tallet, har det nok været Nordens største verdslige stenhus, af 


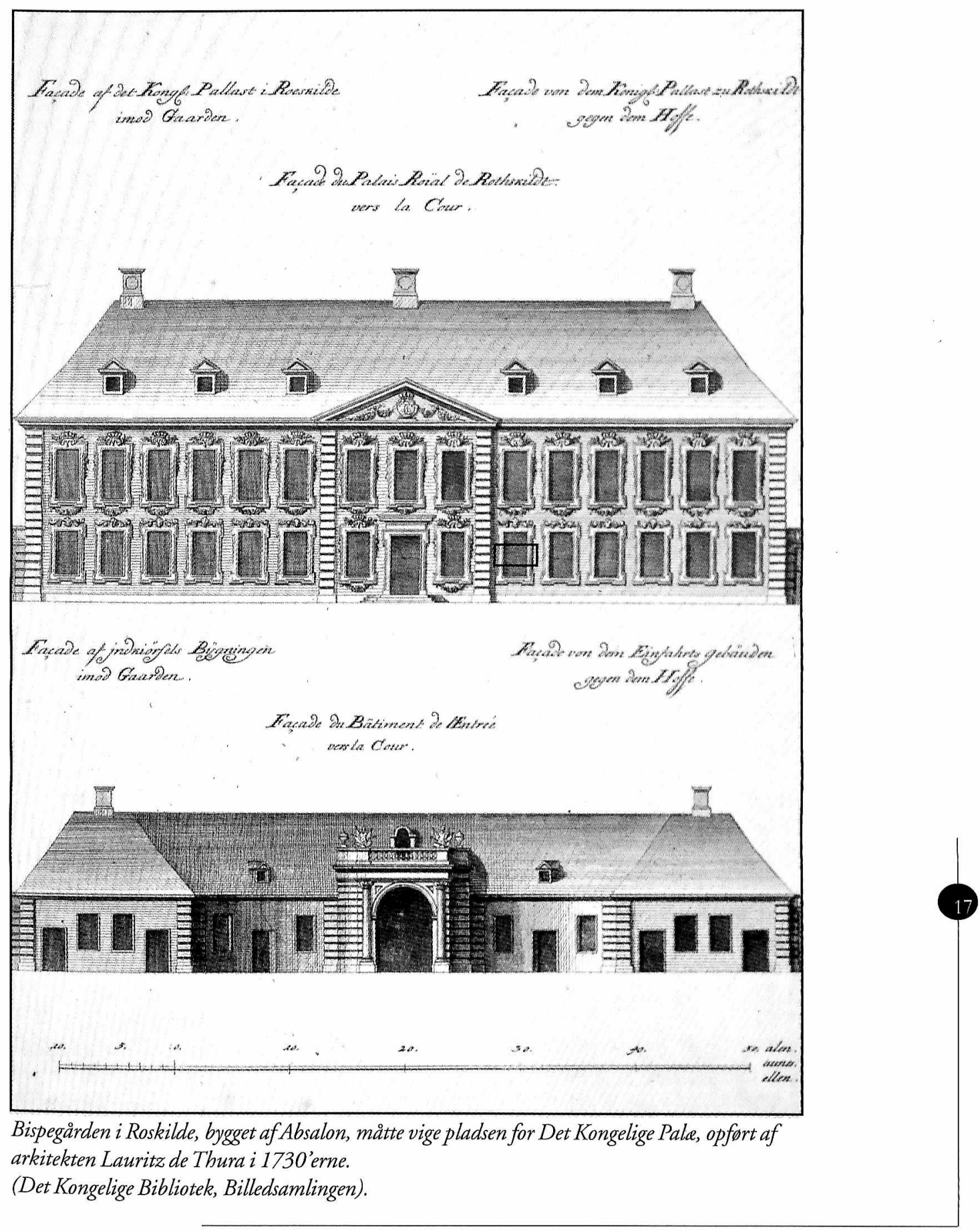


grundareal som et af Amalienborgs palæer, og ville, hvis det havde eksisteret i dag, have været blandt vores fineste verdslige middelalderbyggerier.

Men selv ikke en af landets fremmeste arkitekter i 1700-tallet funderede over denne bispegårds arkitektoniske og historiske kvaliteter. Eller med andre ord: dens uvurderlige værdi som enestående dansk kulturarv. Vi skal lidt længere frem i tid, før arv bliver til kulturarv.

\section{Mennesket $\mathrm{i}$ tiden}

$\mathrm{V}$ 1 skal også frem til en holdningsændring, som bliver fundamental for menneskets opfattelse af sig selv i tid og rum.

Den holdningsændring handler om begrebet tid, som er et dybt eksistentielt begreb og samtidig et af vores mest relative begreber.

Tiden kan opdeles på flere planer. På makroplanet opdeler vi den $\mathrm{i}$ fortid, nutid og fremtid. Fortid og fremtid er udtryk for tidsperspektivet og i princippet uden begrænsninger. Nutid er øjeblikket, skarpt afgrænset af selve eksistensen.

I det meste af vores historie har mennesket kun i meget begrænset omfang kunnet have en rimelig forventning til fremtiden. Sygdom, vold, naturkræfter, hungersnød har været dagligt bevidste trusler, som kun de færreste har været uberørt af. Det har så til gengæld betydet en udtalt fokus på nutiden, for kun i øjeblikkets handling kunne tilværelsen registreres.

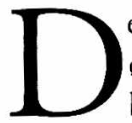
enne koncentration omkring øjeblikket, omkring nutiden, betyder også et helt andet forhold til fortiden. Fortiden var kun for brugt tid at regne, og i materiel forstand var det tidligere skabte uden anden værdi, end den umiddel- bare nytteværdi for nutiden, som kunne konstateres - enten i form af noget man fortsat kunne bruge, eller f.eks. i form af eksisterende bygningers genanvendelighed som byggemateriale, hvis de ikke længere havde nogen funktion.

Der eksisterede selvfølgelig en historieopfattelse, men af en helt anden karakter end vores videnskabeligt funderede, empirisk tilvejebragte historieskrivning. Den "officielle" historie - i det omfang den nu fandtes - tjente nemlig tidligere primært magtens legitimitet - og historien blev skrevet, så den passede til formålet.

I bredere og folkelig betydning arvede man fra fortiden alene en mytologisk/ religiøs forklaringsramme, og fra fortidens slægtled fik man en retslig adkomst til magt, jord, produktionsmidler og social tryghed. Myter og arveret var dengang fortidens bidrag til en nutid.

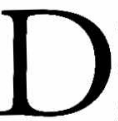
et er i den sammenhæng, vi som sagt skal forstå Absalons kirkebyggeri i 1170 'erne og for den sags skyld også senere tiders kapeltilbygninger til Roskilde domkirke, et byggeri, som uden blusel trænger sig ind på den oprindelige bygningskrop og skaber store brudflader i den originale arkitektur. (I parentes bemærket er det helt typisk for vores egen tid og dens helt anderledes tidsbegreb, at Frederik d. 9's kapel blev bygget $i$ afstand fra Domkirken - eller rettere sagt $\mathrm{i}$ respektfuld afstand, så man på ingen måde hverken direkte eller overført, berører kirken). Hvis vi vender tilbage til tidsbegrebet, så sker der en radikal ændring $\mathrm{i}$ opfattelsen af tid på makroplanet, da livsvilkårene forbedres så betragteligt, at mennesket făr en begrundet forventning om en fremtid.

Først og fremmest flytter man 


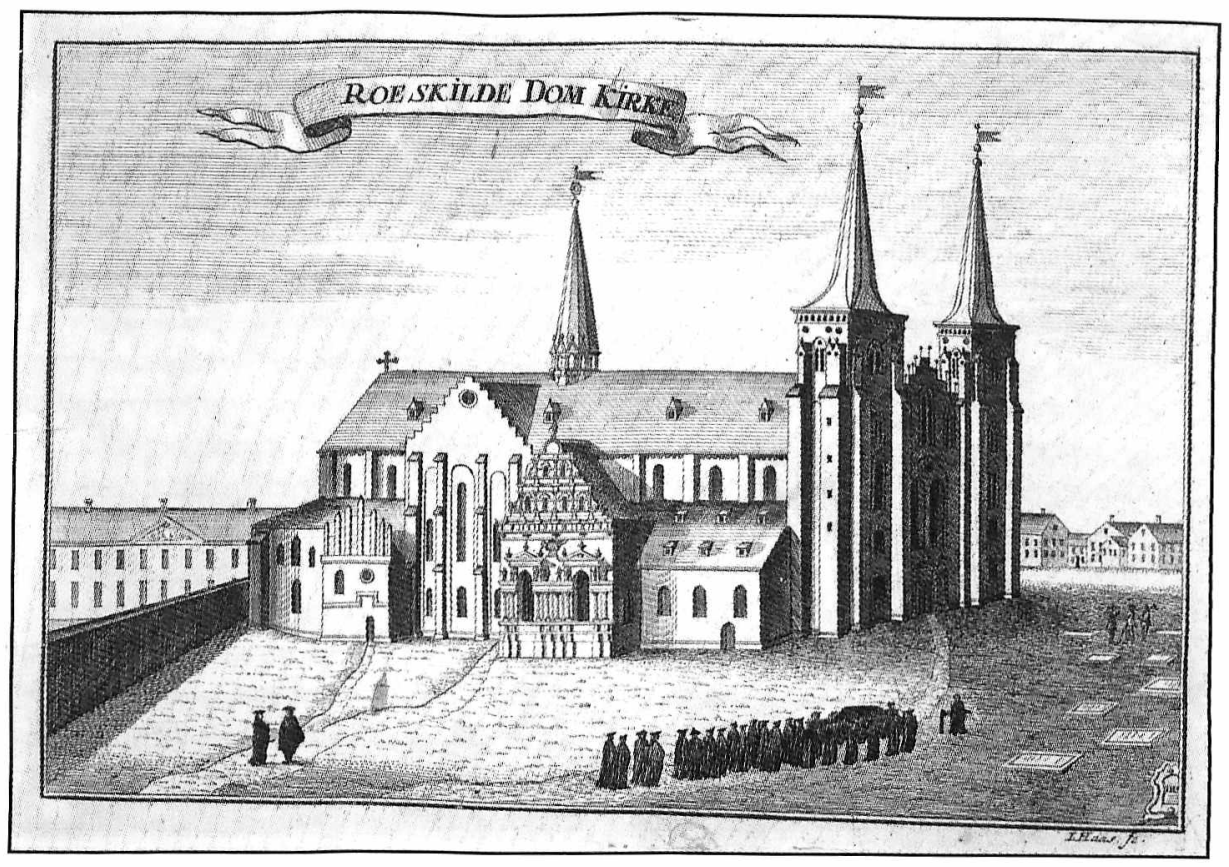

Roskilde Domkirke figurerer på UNESCO's liste over verdens umistelige kulturarv. Det oprindelige kirkebyggeri fra $1170^{\prime}$ 'rne, der er condret flere gange op gennem tiden, skaber store brudflader i den originale arkitektur.

(Det Kongelige Bibliotek, Billedafdelingen).

sine forventninger fra nutiden over på fremtiden og trækker dermed i realiteten også dynamikken ud af øjeblikket.

Det er i den samme bevægelse, at fortiden - også i materiel forstand, făr en betydning. Man begynder nu at erkende i perspektivet i stedet for i øjeblikket, og trækker samtidig linjerne bagud, fordi en fremtid er meningsløs uden fortidens perspektiv. Forventning er funderet på erindring, hvorfor forventning hyppigt opleves og udtrykkes som noget relativt. Sagt på en anden måde forventer vi, at udviklingen bringer os noget der kan gradbøjes, altså noget der er bedre, større, hurtigere osv.
Museerne -

det legale rum for alles historie

å i og med denne nye optagethed af

tidsperspektivet i stedet for af øjeblik ket, kommer der en ændret opfattelse af erindring - også i betydningen bevaring. Det er også i den proces, at man skal finde en fremvoksende interesse for museumstanken, en udvikling, der finder sin naturlige forløsning i det gryende danske demokrati fra midten af 1800-tallet. Tankevækkende er det så, at demokratiet i moderne betydning og dermed også interessen for kulturarv, samtidig er nært knyttet til nationalismen, som i princippet er en sky og 
defensiv tankegang.

Men det er altså her i dette europæiske tidehverv i sidste halvdel af 19 . århundrede, at museerne opstår.

For at forstå det, skal man først erkende museernes art som kulturarvens testamente, det sted hvor boet gøres op og tilskrives de kommende generationer.

Det får en særlig betydning, når det ses i sammenhæng med de rettigheder, som demokratiet medfører, nemlig at alle befolkningsgrupper får stemme både politisk og i overført betydning.

$1 \begin{aligned} & \text { lle - i hvert fald på sigt alle - bliver } \\ & \text { indskrevet i samfundsbeskrivelsen } \\ & \text { med samme valeur. Blev man ikke }\end{aligned}$ med demokratiet økonomisk lige med de gamle herskende klasser, så blev man dog ligeværdig med dem.

Det gav samfundets grupperinger en helt ny og hidtil uset selvbevidsthed og en trang til at præsentere sig for de andre, fortælle sin historie og demonstre sin legitimitet og sine bidrag til nationens udvikling. Man ville simpelthen gerne skrive sin arv ind $i$ testamentet.

Med demokratiet fik således alle geografiske områder og alle sociale grupper i landet et ønske om at præsentere sin historie og en politisk og social mulighed for at gøre det. Museerne blev bogstavelig talt det legale rum for alles historie.

Efter tur skabte bønder, håndværkere, købmænd, industriarbejdere og funktionærerne, såvel som vendelboere, samsinger, roskildensere og københavnere på eget initiativ deres museer, og synliggjorde dermed deres eksistens, deres vilkår og deres forudsætninger. Hele denne proces var også afgørende for den enkeltes mulighed for at finde fodfrste, dengang det gamle bondeland for alvor kom $\mathrm{i}$ opbrud og industrialis-

men med dens byer, nye socialklasser og andre vilkår for tryghed, voksede frem.

$\mathrm{D}$ en første bølge af museums grundlæggere, bønderne i herredet, borgerskabet i stiftsbyen og mæcenerne i hovedstaden blev senere efterfulgt af en række andre, der ønskede museer, som var funderet i tværgående emner, som så at sige forholdt sig horisontalt til kulturarven. Det var museer om søfart, teknik, militær, osv., emnegrupper, som det var helt nyt, at betragte som kulturarv.

\section{M}

\section{har hukommelsens karakter} useerne er, som også kulturarv og kulturværdi, højst labile størrelser. Således præges deres funktion af et tilfældighedsprincip af anseelig dimension.

Jeg karakteriserede for nogle år siden museet således:

„Et museum er ingen ufejlbarlig facitliste til kulturarven, intet altforklarende leksikon over fortidens hændelser. Et museum rummer den kollektive hukommelse og har derfor hukommelsens karakter.

Museets samlinger er en blanding af nedarvet erindring, genfunden viden - og tilfældigheder.

Det tilbyder ingen absolut sandhed, men udtrykker stadier i vores søgen efter det glemte og vores fortolkning af det genfundne. Et museum spejler derfor både fortiden og sin egen samtid.

Museerne er skabt af en almen drift, som for den enkelte handler om at forstå sin egen position både i tid og rum. Derfor skal adgangen til kulturarven være uhindret og uden pålagte fortolkninger fra den til enhver tid siddende magt, for kun således kan den enkelte erkende sine forudsætninger og forstå sit tilhørsforhold til 
det historiske fællesskab, som er ethvert samfunds bindemiddel.

M useet tilvejebringer sin samling gennem målrettet undersøgelse og forskning - men tillige ved en vilkårlig proces, hvor befolkningen aktivt medvirker gennem indlevering af genstande og oplysninger. Det sidste er et kulturelt særkende for museerne - og demonstrerer den almene optagethed af at huske - og blive husket.

Det er $\mathrm{i}$ udstillingerne, at museet fremlægger sin fortolkning af samlingernes udsagn. Det gøres af de på det givne tidspunkt værende medarbejdere på grundlag af de på samme tid værende samlinger.

I morgen kan en heldig arkæologisk udgravning, et genfunden brev, en ny tolkningsmetode ændre vores viden dramatisk.

Men er kulturarven fælles eje, forbliver den kun fælles, hvis den er tilgængelig. Derfor må museerne med mellemrum fiksere den videnskabelige tolkningsproces og fremlægge resultaterne. I udstillingen har museet valgt side. Man har udvalgt de genstande, som mest præcist menes at beskrive historien og kulturarven - men dermed også fravalgt et stort antal genstande“.

$\mathrm{N}$ år vi således træder ind på et museum, så træder vi altså ind $\mathrm{i}$ tilfældighedens rum. Men samtidig må man fastslå, at vi træder ind i et rum, hvor tilfældighederne er både fortolket og ordnede. For selvfølgelig kan videnskaben i et vist omfang gennem sine metoder og empirisk opsamlede viden korrigere, og den bliver bedre og bedre til det gennem en målrettet metodeudvikling. Men det ændrer ikke ved det grundlæggende vilkår, som også blev vist af bygningerne i Roskilde: at det er tilfældigt og begrænset, hvad det er af den materielle kulturarv, der har overlevet til i dag. Jo længere vi går tilbage i tiden, jo mere udtalt bliver tendensen. Det der findes i dag, fra f.eks. Danmarks oldtid, er genstande der på næsten mirakuløs vis har fundet vej til museets montre. Oprindeligt er meget af det affald, der er endt $\mathrm{i}$ jordlag, hvor det bevares. Her skal det så oven i købet genfindes af en arkæolog eller en, der kan forstå dets betydning. Kun i meget få tilfælde har genstande haft en sådan betydning og pragt, at mennesker generation efter generation har skærmet og bevaret dem. Langt den meste kulturarv har så at sige måttet klare sig selv.

Kan man dokumentere sin egen tid? et er vigtigt, at man er sig disse
vilkår bevidst, også fordi at jo
tættere vi kommer på vores egen tid, jo mindre udtalt bliver tilfældighedskriteriet. Her i det vi kalder nyere tid, kan vi $i$ langt højre grad selv styre indsamlingen og når vi kommer frem til vores samtid, kan man næsten sige, at der er frit valg på alle hylder. Det kan umiddelbart synes meget positivt, men det kræver i høj grad nøje overvejelser. For i realiteten kan det forhold betyde, at hele vores relative historieopfattelse fortegnes og kæntrer. Nu står vi jo pludselig med en enkelt historisk periode, der har en næsten komplet bevaret åndelig og materiel kulturarv, som vi oven i købet selv kan have erindring om - og den skal sammenholdes med tidligere perioders meget fragmenteret overleveret kulturarv. Det kan let give et falsk sammenligningsgrundlag.

Vi er alle med mellemrum mere eller mindre ofre for denne fortegnede 


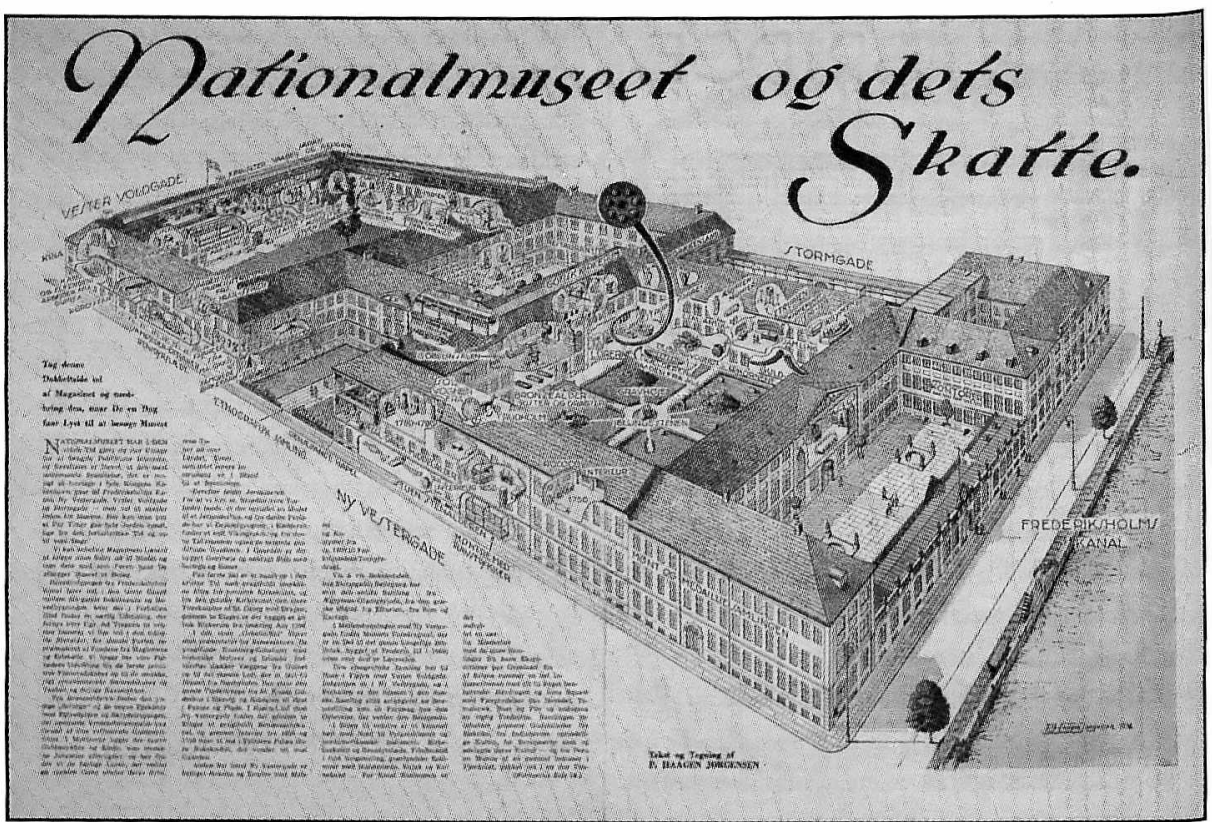

Nationalmuseet er Danmarks kulturhistoriske centralmuseum med hoveddomicil $i$ Prinsens Pale $i$ København. Museet har rødder i Det Kongelige Kunstkammer, der blev grundlagt ca. 1650. (Det Kongelige Bibliotkek, Billedsamlingen).

historieopfattelse. F.eks. anser de fleste af os nok tidligere tiders mennesker som primitive og teknisk tilbagestående i forhold til os nutidsmennesker. Det gælder både for en nær og en fjern fortid.

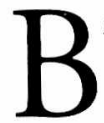
ronzealderens mennesker f.eks., ser mange for sig som simple vildmænd, klædt i skind. Men intet kan være mere fejlagtigt. Bronzealderkulturen var øjensynligt en avanceret kultur, måske relativt betragtet mere avanceret end vores egen. Bronzealdermenneskets åndelige begrebsverden og følelsesregister har været lige så udvikdet som vores. $\mathrm{Og}$ deres materielle færdigheder har selvfølgelig været anderledes, men mindst lige så skikkede til at løse de udfordringer, som dagligdagen stillede. Og det er en væsentlig pointe. For selvom det næsten er umuligt at opstille et kvalitetsparameter til sammenligning af kulturer, så er det et godt sted at måle kvaliteten, hvis man ser på en given kulturs evne til at finde løsninger på de udfordringer, som den konfronteres med og som skal løses, for at den ønskede udvikling skal fastholdes. Vi kender kun begrænset til bronzealderens materielle kultur og endnu mindre til den immaterielle. Og slet ikke nok til at forstå kulturen i sin totalitet. Når vi så står med en stort set komplet viden om vores egen materielle og åndelige kultur, så drager vi let nogle falske konklusioner i sammenligningen.

Især på det immaterielle område er vi - næsten bogstaveligt - på Herrens mark. 


\section{Øjeblikkets historie}

$\mathrm{J}$ eg plejer at sige, at vi desværre aldrig i en arkæologisk udgravning har fundet det glade smil, det faste håndtryk, den Thderlige bøn eller den engagerede forsvarstale. Vi kender stort set intet til det, som faktisk udgør fylden i vores egen dagligdag, nemlig den menneskelige omgang, og vores menneskelige ytringer i denne omgang.

Der er jo en historie, som er øjeblikkets. En stemning, der er lige så flygtig som tiden, en stemning som ikke kan gribes og konserveres, ja ikke engang kan genfortælles. Den lever og dør med øjeblikket, og det er netop her, at det levede liv adskiller sig fra det erindrede liv. Det kan ingen historiker beskrive, det kan ikke belægges med kilder - og så er det alligevel selve historiens fysiognomi. Hvis historie skulle være et forsøg på at beskrive det levede liv og dets vilkår, så er denne øjeblikkets historie vores mest umistelige kulturværdi - men også den, som vi aldrig kan bevare.

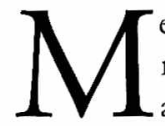

en vender vi tilbage til den materielle kultur, så kan man, for at nivellere skævhederne i sammenligningsgrundlaget, polemisk sige, at det skulle være forbudt at indsamle fra sin samtid. Den „fordel“, som de sidste 100 år har, som den eneste periode $i$ historien at være samtidig med museerne, burde museerne selv være med til at korrigere for. Vores tids genstande burde først indsamles af fremtidens museer. Kun derved ville vi forstå historiens vilkår - og i øvrigt er der ingen epoke som kan forstås i sin samtid. Skal man forstå en given periodes særkende, en given begivenheds konsekvens og en given opfindelses betydning, skal de vurderes i et langt tidsperspektiv.

Til en vis grad er princippet allerede accepteret $\mathrm{i}$ lovgivningen, både i bygningsfredningslovens bestemmelser om alder, inden en bygning kan fredes - og også i Kulturværdilovens aldersbestemmelser. Man opererer således med tidsgrænser på 50 eller 100 år inden en genstanó eller en bygning omfattes af lovens bestemmelser, fordi man kun i perspektivet kan vurdere objektets egentlige værdi.

\section{Foranderlighed som princip}

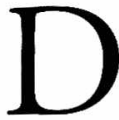
isse betragtninger betyder selvfølgelig ikke, at vi skal ændre vores opfattelse af kulturarvens betydning eller f.eks. lødigheden af et begreb som kulturværdi. Men vi skal erkende vores vilkår.

For når det kommer til stykket er kulturarv og kulturværdi jo ikke er hypotetiske begreber, men meget bogstavelige, der selvfølgelig har deres udgangspunkt i den reelle verden. Men den reelle verden er også foranderlig, eller rettere vurderingen af den. Hver eneste generation afprøver tidligere generationers afgørelser. Også i det forhold kommer begrebets foranderlighed til udtryk.

Det er bl.a. derfor, at det må fastholdes, at der ikke kan udskilles ved kassation eller salg fra museernes samlinger. For ligesom opfattelsen af hvad der f.eks. er umistelig kulturarv kan forandre sig, således kan opfattelsen af, hvad vi kan kassere som uinteressant også forandre sig.

lle har vi eksempler på genstande,
som ingen tidligere tog notits af,
men som nu pludselig ophøjes til umistelig kulturværdi. Ikke mindst indenfor kunstens verden kendes fænomenet. Hammershøj er et eksempel blandt mange på en maler, som blev flyttet fra de mørke siderum til museets hovedvæg. 


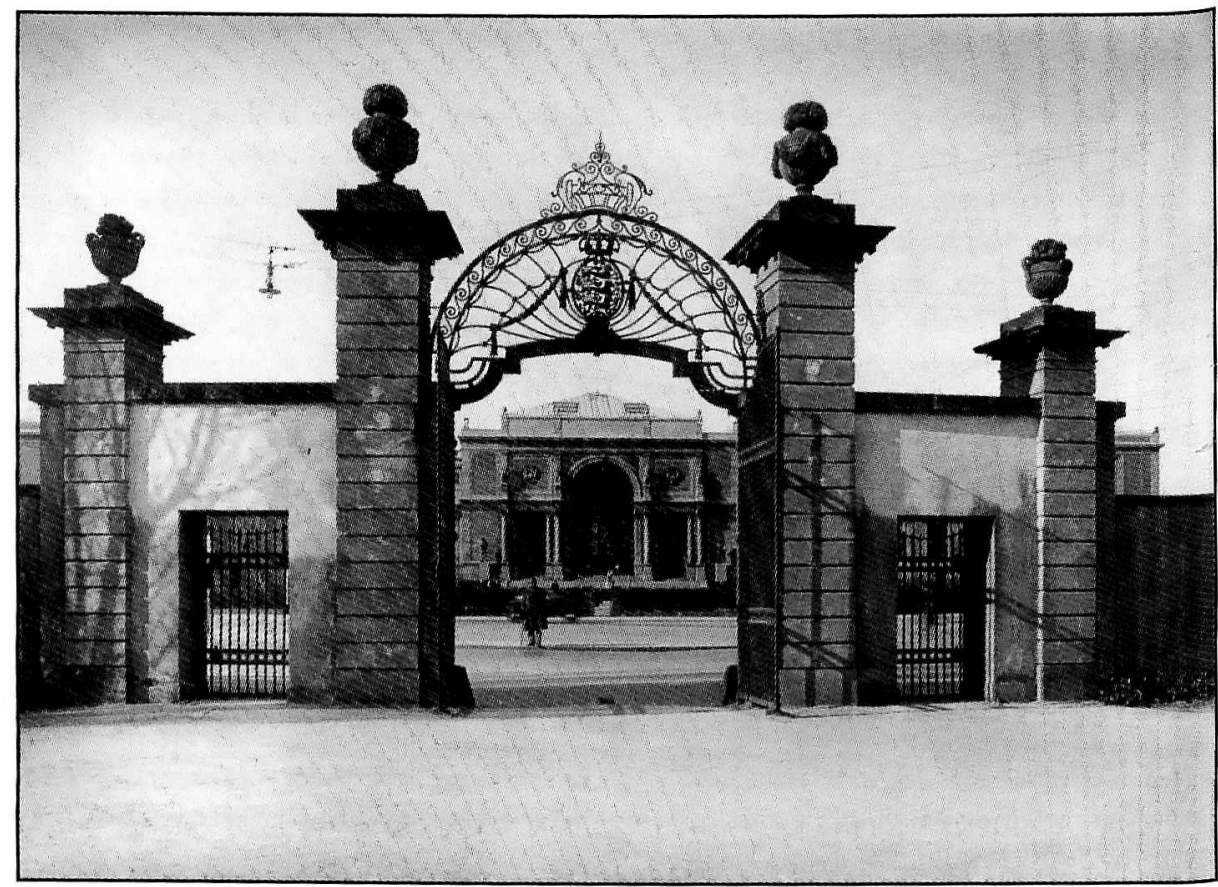

Statens Museeum for Kunst i København er Danmarks nationale galleri og hovedmuseum for billedkunst. Ikke mindst blandt malerier er der mange eksempler pä, at genstande, som ingen tidligere tog notits af, pludselig kan ophøjes til umistelig kulturarv. (Billedasamlingen).

kulturarv sker der præferenceskift, enten fordi alder har gjort noget til sjældenhed, eller fordi vi har ændret vores opfattelse af dets betydning. Det kan så skyldes ny viden eller bedre fortolkningsmetoder. Men det kan også skyldes noget så uforudsigeligt og tilfældigt som ændret smag.

Det er klart, at der er objekter i vores kulturarv, som til alle tider vil blive betragtet som nationale ikoner, eller rettere sagt, som vi må antage til alle tider vil blive betragtet som sådan. For menneskets opfattelse af tilværelsens vilkår er heller ikke stabil. Ingen kan forudsige om vi igen făr en tid med en historieopfattelse, som ikke omfatter materiel kulturarv. Eller en "posthistorisk" tid, hvor vi igen skrotter perspektivet og koncentrerer hele vores

opmærksomhed om øjeblikket. Der er jo i alle menneskelige forhold et traditionelt reaktionsmønster, som tilsiger, at når en udvikling har nået et mætningspunkt, eller måske oven i købet det punkt, hvor udviklingen beskrives ved sin egen karikatur, så reagerer vi med en modsat rettet bevægelse.

Der er ikke i dag nogen som helst tegn i planeterne på, at vores holdning til kulturarv er ved at ændre sig.

Men derfor kan man godt notere sig udviklingens stade og retning engang $i$ mellem.

vis vi f.eks. ser på bygningsbevaring, på vores bestræbelser efter at frede og istandsætte ældre 
bygninger, så har ideen aldrig været praktiseret mere udtalt i vores historie, end det bliver $i$ dag. Man kan roligt sige, at i visse situationer kan bevaringen næsten stå i vejen for vores egen tids mulighed for at udtrykke sig.

Dermed bliver bevaring af fortidens frembringelser faktisk et nutidigt udsagn på linje med original nyskabelse. Det jeg mener er, at bevaring og restaurering af ældre bygninger i dag betragtes som et restetisk og socialt højt estimeret bidrag til nutidens bygningskultur, og det vurderes helt på niveau med nye originale arkitekturfrembringelser. Det er faktisk en interessant udvikling. I øvrigt har den også medført, at vi har særligt uddannede restaureringsarkitekter.

\section{Tælleapparater og politisk korrekthed}

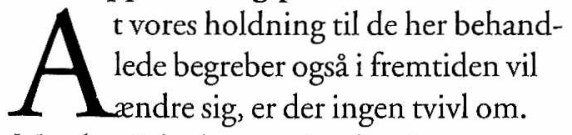

Men hastighed og retning kan ingen forudsige. Dog har vi nok nogle pejlemærker i form af de faktorer, der har betinget den udvikling, vi står midt i.

Det gælder f.eks. museernes demokratiske funktion, den frie tilgængelighed og den frie forskning og formidling.

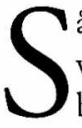
å længe, at vi stadig mener sådan, vil vores opfattelse af kulturarvens betydning antagelig være den samme. I øvrigt kan hele dette spørgsmål om tilgængelighed og uafhængighed ikke overspilles, for det er simpelthen demokratiets vandmærke. Hvis ikke historie og kulturarv er tilgængelig og kildematerialet fremlagt til offentlig efterprøvning af fortolkningerne, så er demokratiet sat ud af spillet. Så fra i sin tid at være et produkt af demokratiet, er museerne blevet en forudsætning for samme.
Det er ikke en fordring vi normalt diskuterer i Danmark eller i det meste af Europa, for den sags skyld. Det betragtes som en selvfølgelighed. Og dog har princippet lidt skibbrud indenfor Europas grænser i de seneste år. På Balkan f.eks. blev historie og kulturarv manipuleret - og nogle af de første ofre for krigene var - foruden sandheden - museer og monumenter. Men faktisk er der også i den danske udvikling små tendenser, som på sigt kan true dette uantastelige demokratiske princip. Disse tendenser har selvfølgelig intet til fælles med situationen på Balkan, men kræver alligevel opmærksomhed, især fordi det der opfattes som selvfølgeligheder let sløver vores beredskab.

Et eksempel er hele vores tids politiske optagethed af talstørrelser, tabeller og grafer, som beskriver besøgstal, egenindrægt og lønsomhed. Denne jeronimuske betagethed af kvantitet, har allerede betydet ændringer i vægtning f.eks. på museerne af videntilvejebringelse i forhold til formidling. Formidlingen tilføres langsomt flere ressourcer på bekostning af forskning og undersøgelse for at kunne modsvare de stillede krav. Indirekte kan politiske ønsker om højere besøgstal således betyde, at kulturarv ikke dokumenteres pga. formindsket beredskab på undersøgelsesområdet.

Der sker desværre også en ændring i selve formidlingens karakter i populistisk retning - som igen er med til at forsimple kulturarvens mangfoldighed.

S amtidig sker der en indirekte styring gennem en stadig stigende mængde af politisk korrekte dagsordner. Den ene dag forventes det, at der tages særlige initiativer overfor børn, så overfor ældre, så overfor handicappede, så overfor etniske minoriteter osv. osv. Kun vanskeligt kan man 
med sin etiske habitus i behold modsige sådanne dagsordner, men der er ingen der siger, at de også nødvendigvis harmonerer med de særlige behov, der måtte opstå i forvaltningen af kulturarven. Tværtimod kan man med ret stor silkkerhed sige, at de ikke gør det. Der har vi så et dilemma, som i sin yderste konsekvens kan blive et demokratisk anliggende. Museer, arkiver og biblioteker er nemlig af samfundet sat til at løse opgaven med forvaltning af og adgang til kulturarven. Vi er områdets advokater i den brede samfundsdebat, og dermed pålagt at forsvare områdets integritet, definere dets behov og anvise afhjælpning af disse behov. Men hvis populistiske krav til besøgstal og skiftende politiske korrekthed tvinger vores opmærksomhed bort fra substansen, så må der noteres tab på den demokratiske konto.

Jeg nærer dog ikke tvivl om, at hvis en sådan udvikling for alvor bliver en trussel, så vil vores ædruelige demokrati trods alt slå hælene i. Men det er vores eget ansvar, at gøre opmærksom på, at nu er tiden inde.

\section{Den autentiske genstand}

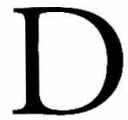
et skal nævnes, at der også er modsat rettede tendenser, som er med til at sikre en endnu højere grad af tilgængelighed, nemlig de informationsteknologiske medier. Målsætningen på det felt er, at gøre vores samlede materielle kulturarv tilgængelig elektronisk og dermed også gøre det muligt for enhver, selv at afprøve en given fortolkning på kildematerialet. Det er en fantastisk udvikling som vil tilvejebringe maksimal gennemsigtelighed.

Men den elektroniske formidling skal opfattes og bruges rigtig. For ellers kommer den i konflikt med museets eksklusive særkende og kerne: den autentiske genstand. Det er jo - når det kommer til stykket - den, det handler om.

Det er den autentiske genstand, der kan blive kulturværdi - aldrig dens kopi eller efterligning eller præsentation på internettet.

Det er den autentiske genstand, som lokker os gennem museets port, hvad enten det er stenøksen på det kulturhistoriske museum eller maleriet på kunstmuseet. Det spiller ingen rolle for vores oplevelse, at genstanden på museet er løsrevet fra sin oprindelig og for altid tabte sammenhæng. Vi ved godt, at vi gennem museets genstande kun får fragmenter af en kode, som beskriver forudsætningerne for vores egen situation, men aldrig den fulde historie. Alligevel giver den autentiske genstand med sine spor af brug denne i princippet umulige oplevelse af, at tidens ellers uoverstigelige barriere er fjernet. Deri ligger genstandens fascination - i den på én gang intime og umiddelbare, men samtidig umulige, kontakt med det forsvundne.

$\mathrm{V}$ ed sin realitet synes den autentiske genstand at ophæve det, der er mest determinerende for eksistens, nemlig tidens gang. - Så længe mennesket evner at opfatte sig selv i perspektivet og ikke kun i øjeblikket, vil de kommunikationslinjer, som genstanden trækker til det, der er forudsætningerne for vores samtid, være væsentlige for vores selvforståelse.

Samtidig repræsenterer det forgangne også noget trygt, fordi det er afsluttet og konsekvenserne er kendte - og det rummer ikke fremtidens uforudsigelighed. Det er forståeligt, at vi derfor gør det til noget værdifuldt - oven i købet noget umisteligt værdifuldt. 


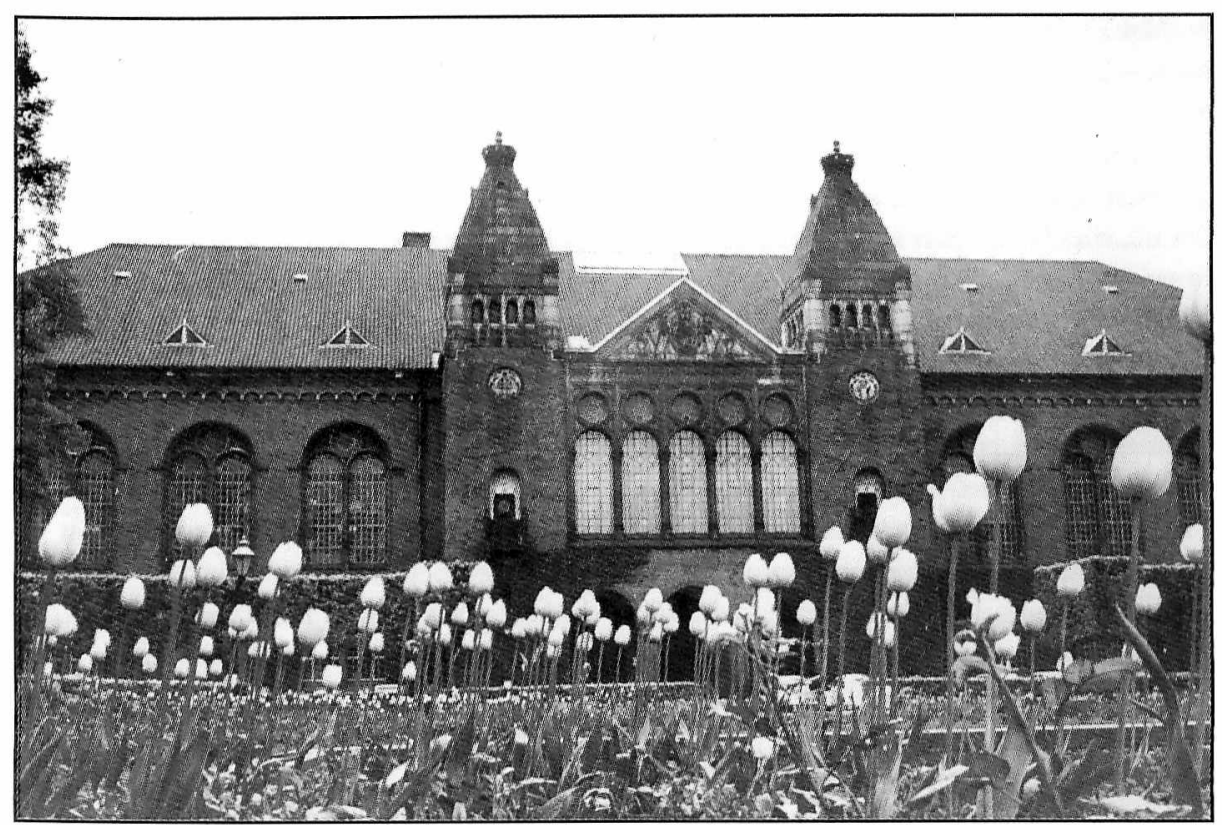

Det Kongelige Bibliotek har eksisteret som nationalbibliotek og museum siden 1648. Genstandene fra fortiden med deres facinerende henvisning til svundne tider bestair her af boger, tidsskrifter, aviser, håndskrifter, kort, fotografier og arkivalier. (Det Kongelige Bibliotek, Billedsamlingen).

\section{Umistelig og mistelig}

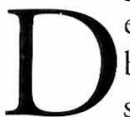
et er i øvrigt interessant, at selv begivenheder, som har betydet større katastrofer i vores historie, kan ende med at producere umistelige kulturværdier. F.eks. er dokumentet for Roskildefreden i 1658, hvor Danmark må afstå Skåne og andre sydsvenske landområder, en umistelig kulturværdi, som vi aldrig ville tillade gik tabt, eller blev eksporteret til udlandet. Der er mange lignende eksempler - helt op til forrige århundrede. Men kommer vi tættere på, oplever vi igen kulturværdibegrebets meget store relativitet. Vi behøver blot at se på de senere års debat i Sønderjylland eller de tyske bunkere ved Vesterhavet, hvor der har været omfattende polemikker om deres bevaringsværdi. Selvfølgelig er bunkerne et væsentligt historisk udsagn og en del af Danmarks bygningsarv. Men ser vi på debatten, findes der også den opfattelse, at der eksisterer mistelig kulturarv, hvis man kan udtrykke det sådan - især hvis man som kulturhistoriker lader sin principielt neutrale holdning til kulturarven styre af populisme.

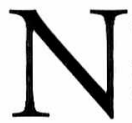
u har vi beskæftiget os med den foranderlighed, der knytter sig til begreberne kulturarv og kulturværdi. Til sidst vil jeg opholde mig lidt ved nogle andre sider af begreberne. F.eks. deres rummelighed. I Europæisk opfattelse er kulturarv næsten eksklusivt knyttet til materiel kultur, om end selvfølgelig i utallige former. Men f.eks. i Japan kan en umistelig kulturværdi - eller national treasure, som man kalder det i engelsk udgave - godt 
omfatte noget så skrøbeligt, som levende mennesker - eller rettere, deres færdigheder. Flere af de gamle håndværk og ceremonier, f.eks. lakarbejde, skrivning af skrifttegn og den traditionelle teceremoni, forsøger man at bevare, eller så at sige at frede, gennem livsvarige ydelser til de personer, der behersker færdighederne. De bliver registreret som national treasure - og forpligter sig til, som en del af hele ideen, at modtage lærlinge og gennem dem lade færdighederne leve ind $i$ fremtiden.

Også i Danmark har vi efterhånden fået øjnene op for nogle af elementerne i ideen og gør $-i$ en formel reduceret udgave - bl.a. noget for bevaring af gamle håndværk $\mathrm{i}$ Bevaringscenteret $\mathrm{i}$ Ørholm.

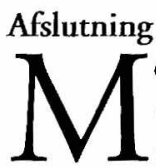

ed det 19. og 20. århundredets udvikling af teknikker er der tillige skabt veje for bevaring af autentiske menneskelige ytringer i form af lyd og billede. Den fortsatte udvikling $\mathrm{i}$ vores århundrede af elektroniske medier vil uden tvivl til stadighed forøge mulighederne for bevaring - også langt ud over vores fatteevne. Helt uberegnelig forekommer forskningen i genteknologien og dens potentiale for med tiden at kunne "vække" arvemasse fra for længst uddødt liv og for at klone det eksisterende.

Men måske er det der, hvor vi nærmer os et karrikeret udtryk for udviklingen, som vil starte en modsatrettet bevægelse.

$\mathrm{K}$

ulturarv og kulturværdi fylder efterhånden meget $\mathrm{i}$ vores debat og $\mathrm{i}$ es bevidsthed

Vi gør meget, og vi gør det på mange planer: for den personlige kulturarv i form af fotoalbum og arvestykker til de store nationale manifestationer. Vi lovgiver i stigende grad for at sikre, at vi har de tilstrækkelige adkomster og ressourcer til arbejdet. Netop nu har vi fået ny museumslov, som i princippet pålægger os alle sammen, at medvirke til at sikre den arkæologiske arv, hvis vi med vores initiativer truer den. Vi prøver også at udforme fælles regler for hele verden $\mathrm{i}$ internationale fora, som f.eks. i UNESCO - eller fælles vilkår indenfor EU.

\section{Hvor hele bestræbelsen i EU} sædvanligvis går ud på at understrege det fælles og arbejde for ensartethed, så er feltråbet på kulturområdet mangfoldighed. Vi hæger - selv i fællesskabets enhedsbestræbelser - om de nationale eller etniske særtræk i den europæiske kulturgeografi. Samtidig bygger man over hele Europa nye museer, for man vil gerne vise sin formåen, sin pragt, sit særkende - eller med et andet ord, sin kulturarv - på den mest præsentable måde overfor sine nye partnere og kollegaer. Vi ved jo godt, hvad det er, der giver prestige.

$\mathrm{M}$ en på trods af alle disse bestræbelser og hele denne optagethed er det faktisk sådan, at begrebet kulturarv stort set ikke er defineret. Det mere kvalificerende begreb kulturværdi er beskrevet $\mathrm{i}$ kulturværdiloven - men er ellers lige som kulturarv, stort set fraværende i vores formelle sprog og $\mathrm{i}$ vores "autoriserede" fortolkningsmedier. Således optræder ordene alene i retskrivningsordbogen, men ikke i Ordbog over det Danske Sprog, i Nudansk Ordbog-eller i Encyklopædien.

Det er ikke uinteressant - men måske er det så alligevel betryggende, at vi i Danmark kan være så optaget af begreber, som vi end ikke har fået formelt funderede. 